\title{
Notes on taxonomy and biology of the symbiotic shrimp Vir euphyllius Marin et Anker, 2005 (Decapoda: Palaemonidae: Pontoniinae), associated with scleractinian corals Euphyllia spp. (Cnidaria: Caryophyllidae)
}

\author{
I.N. Marin \\ Laboratory of ecology and morphology of marine invertebrates, A.N. Severtzov Institute of ecology \\ and evolution RAS, Leninsky prospect, 33, Moscow, 117071, Russia. \\ e-mail: coralliodecapoda@mail.ru
}

ABSTRACT: Recent collections of numerous specimens of shrimps associated with cariophyllid corals in Nhatrang Bay, Vietnam, add new data to the taxonomy and biology of the pontoniine shrimp Vir euphyllius Marin et Anker, 2005. A comparison of the morphology and coloration of the freshly collected specimens with the type material of $V$. pareuphyllius Marin et Anker, 2005 and $V$. euphyllius leads to the conclusion that $V$. pareuphyllius should be considered as junior synonym of $V$. euphyllius. A key to the species of the genus Vir Holthuis, 1952 is provided. In Nhatrang Bay, $V$. euphyllius is exclusively associated with three species of the caryophyllid coral genus Euphyllia Dana, 1846. The shrimps appear to live in heterosexual pairs and are possibly territorial and aggressive towards conspecifics.

KEYWORDS: Vir, Euphyllia, corals, Palaemonidae, symbiosis, Nhatrang Bay, Vietnam.

\section{Замечания к таксономии и биологии симбиотической креветки Vir euphyllius Marin et Anker, 2005 (Decapoda: Palaemonidae: Pontoniinae), ассоциированной со склерактиниевыми кораллами Euphyllia spp. (Cnidaria: Caryophyllidae)}

\section{И.Н. Марин}

\begin{abstract}
Лаборатория экологии и морфологии морских беспозвоночных, Институт экологии и эволюичии им. А.Н. Севериова, Ленинский проспект, 33, Москва, 117071, Россия.

e-mail: coralliodecapoda@mail.ru
\end{abstract}

РЕЗЮМЕ: Новые сборы симбиотических креветок, ассоциированных с коралламикариофиллидами в заливе Нячанг, Вьетнам, существенно дополнили данные о таксономическом положении креветки-понтониины Vir euphyllius Marin et Anker, 2005. Сравнение морфологии и окраски собранных недавно животных с типовым материалом Vir pareuphyllius Marin et Anker, 2005 и V. euphyllius позволило заключить, что V. pareuphyllius является младшим синонимом V. euphyllius. В работе представлен ключ для определения видов рода Vir Holthuis, 1952. В заливе Нячанг особи V. euphyllius ассоциированы 
исключительно с тремя видами кораллов рода Euphyllia Dana, 1852. Креветки заселяют хозяев гетеросексуальными парами, возможно, территориальны и агрессивны по отношению к конспецифичным особям.

КЛЮЧЕВЫЕ СЛОВА:Vir, Euphyllia, кораллы, Palaemonidae, симбиоз, Нячанг, Вьетнам.

The genus Vir Holthuis, 1952 was erected for Palaemonella orientalis Dana, 1852 (Holthuis, 1952). Since then four species, Vir philippinensis Bruce et Svoboda, 1984, Vir colemani Bruce, 2003, Vir euphyllius Marin et Anker, 2005 and Vir pareuphyllius Marin et Anker, 2005, have been described (Bruce et Svoboda, 1984; Bruce, 2003; Marin et Anker, 2005) and existence of further undescribed species has been mentioned (Marin et Anker, 2005). The two most recently described species, $V$. euphyllius and $V$. pareuphyllius were found in Nhatrang Bay, southern Vietnam, in association with hammer corals of the genus Euphyllia Dana, 1846 (Caryophyllidae) (Marin et Anker, 2005). These two species appeared to be morphologically very similar, differing mainly in the shape of the rostrum, different configuration of lobes on the distal margin of the carpus of the second pereiopods, and the size of the mandibular palp (Marin et Anker, 2005). The color patterns of $V$. euphyllius and $V$. pareuphyllius were also very similar. Therefore, Marin et Anker (2005) did not exclude that these two species may actually belong to one and the same species, however, the available material did not allow any further conclusions.

More recent intensive investigations in Nhatrang Bay in September - November, 2005 resulted in the collection of additional material of Vir specimens from three coral hosts Euphyllia divisa Veron et Pichon, 1980, E. parancora Veron, 1990 and E. glabrescens (Chamisso et Eysenhardt, 1821). In total, more than 50 specimens of these shrimps from 21 coral colonies were collected. A thorough comparison of morphology and coloration of all these specimens leads to the conclusion that $V$. pareuphyllius (described in Marin et Anker, 2005: 123) should be considered as junior synonym of $V$. euphyllius (described in Marin et Anker, 2005: 118) by page priority. A rediagnosis of V. euphyllius and an updated key to species are provided. Some newly observed ecological and biological data on $V$. euphyllius is also presented.

Carapace length (CL, in $\mathrm{mm}$ ), postorbital carapace length (PCL) and total body length (TL) are used as standard length. Material is deposited in author's collection in Laboratory of ecology and morphology of marine invertebrates, A.N. Severtzov Institute of ecology and evolution, Russian Academy of Sciences, Moscow (LEMMI).

Genus Vir Holthuis, 1952

Vir euphyllius Marin et Anker, 2005

Vir philippinensis. - Bruce et Svoboda, 1984: 87 (part: paratype female), fig. 66. - De Grave, 2000: 145 (part: specimens from Laing Islands) (not $V$. philippinensis Bruce et Svoboda, 1984).

Vir euphyllius Marin et Anker, 2005: 118, figs. 1-5 (type locality: Nhatrang Bay, Vietnam).

Vir pareuphyllius Marin et Anker, 2005: 123, figs. 68, 9a (type locality: Nhatrang Bay, Vietnam).

Type material. Vietnam: Nhatrang Bay: Tre Is., southern bay, near lighthouse, depth $15 \mathrm{~m}$, on Euphyllia cf. divisa, scuba, coll. I. Marin, 29.06.2004-1 ovigerous female (CL $4.0 \mathrm{~mm}$ ), ZMMU Ma 5452 (holotype of Vir euphyllius); 1 male (CL $2.8 \mathrm{~mm}$ ), ZMMU Ma 5453 (allotype of Vir euphyllius), Tre Is., northern part of "Tre Bay", depth $7 \mathrm{~m}$, on Euphyllia cf. parancora, scuba, coll. I. Marin, 01.10.2003 - 1 female (CL $3.3 \mathrm{~mm}$, dissected), ZMMU Ma 5457 (holotype of Vir pareuphyllius); 1 male (CL $2.5 \mathrm{~mm}$ ), ZMMU Ma 5458 (allotype of Vir pareuphyllius).

Addition material. Vietnam: Nhatrang Bay: Tre I., southern bay, near lighthouse, depth $15 \mathrm{~m}$, on Euphyllia cf. divisa, scuba, 29.06.2004-1 ovig. female (CL 3.2 $\mathrm{mm}$ ), 1 ovig. female (CL $3.8 \mathrm{~mm}$, dissected), 1 non-ovig female (CL $3.4 \mathrm{~mm}$ ), ZMMU Ma 5454-5455; Mun I., southern side, depth $15 \mathrm{~m}$, on Euphylliacf. divisa., scuba, 06.10.2003 - 1 ovig. female (CL $3.9 \mathrm{~mm}$ ), ZMMU Ma 5456; Dun I., depth 15-20 m, onE. parancora, 11.11.2005 -13 ovig. females, 8 males and 2 juveniles; Mot I., depth 10-15 m, on E. glabrescens, 6-11.11.2005 - 5 ovigerous females and 5 males; Mun I., depth 15-20 m, on E. divisa -4 ovig. females and 4 males, 11.11.2005. 


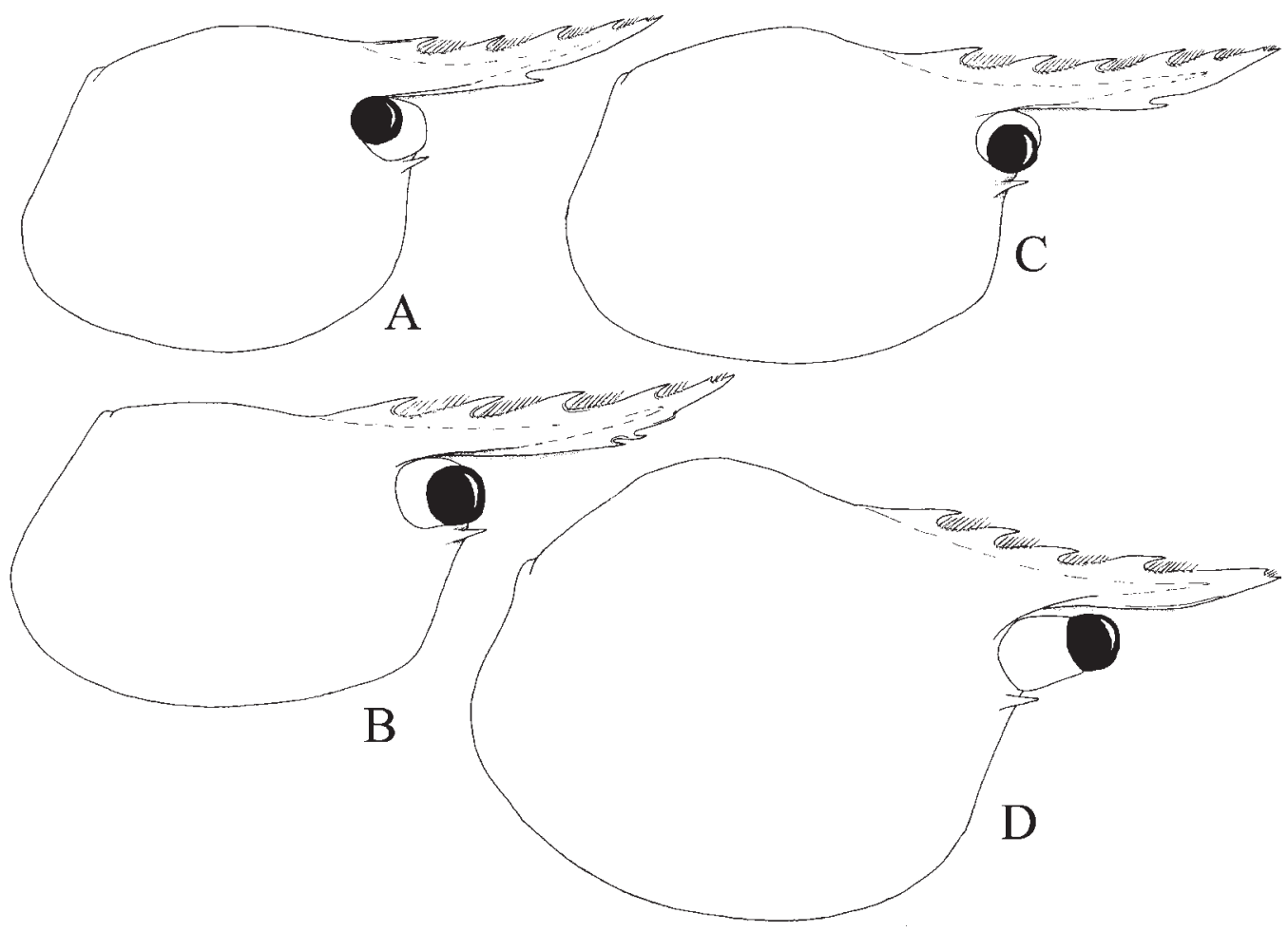

Fig. 1. Rostrum and carapace of Vir euphyllius Marin et Anker, 2005.

A - ovigerous female, PCL - $4.1 \mathrm{~mm}$, from coral Euphyllia parancora Veron, 1990; B - mature male, PCL - 2.6 $\mathrm{mm}$, from coral Euphyllia parancora Veron, 1990; C - ovigerous female, PCL - $3.6 \mathrm{~mm}$, from coral Euphyllia divisa Veron et Pichon, 1980; D - ovigerous female, PCL $4.1 \mathrm{~mm}$ from coral Euphyllia glabrescens (Chamisso et Eysenhardt, 1821).

Рис. 1. Рострум и карапакс Vir euphyllius Marin et Anker, 2005.

А - яйценосная самка, PCL — 4,1 мм, с коралла Euphyllia parancora Veron, 1990; В — половозрелый самец, PCL - 2,6 мм, с коралла Euphyllia parancora Veron, 1990; C — яйценосная самка, PCL - 3,6 мм, с коралла Euphyllia divisa Veron et Pichon, 1980; D — яйценосная самка, PCL — 4,1 мм, с коралла Euphyllia glabrescens (Chamisso et Eysenhardt, 1821).

New diagnosis. Medium sized pontoniine shrimp. Carapace smooth, conspicuously swollen in females (Fig. 1, 2A), only slightly inflated in males; with antennal spine; supraorbital, epigastrical and hepatic spines absent. Rostrum well developed, straight or slightly upturned distally, slightly extending beyond distal margin of antennular peduncle; with $0-2$ ventral teeth; dorsal lamina extending posteriorly well behind orbital margin, with 4-5 well developed subequal teeth and minute distal tooth situated slightly behind the tip of the rostrum, each with setae distally, occasionally most posterior or 2 posterior teeth situated behind level of orbital margin; tip of the rostrum acute or bifid, with setae at notch. Mandible with 1- or 2-segmented palp. Second pereiopods (chelipeds) equal in length and similar in shape; merus slender, about 5 times longer than wide, distally with small rounded projection; carpus slightly shorter than merus, widening distally; dorsolateral margin with 2 rounded lobes and distinct notch between them; fingers about half palm length, with hooked, acute tips; cutting edge of pollex sharp, with 2 large subtriangular and 3-4 small, irregular teeth on proximal half; cutting edge of dactylus sharp, with 2 large triangular teeth around mid-length, without proximal fossa. Third pereiopod slender, when fully extended exceeding mid-length of scaphocerite approximately by length of dactylus; carpus with disto-dorsal angle triangular, slightly projecting; propodus about 9 times longer than broad, twice longer than carpus, dorsal margin without setae or spines, ventral margin with minute setae and 2 small spines disto-ventrally; dactylus simple, with distinct angular projection proximally; unguis slender and curved. 


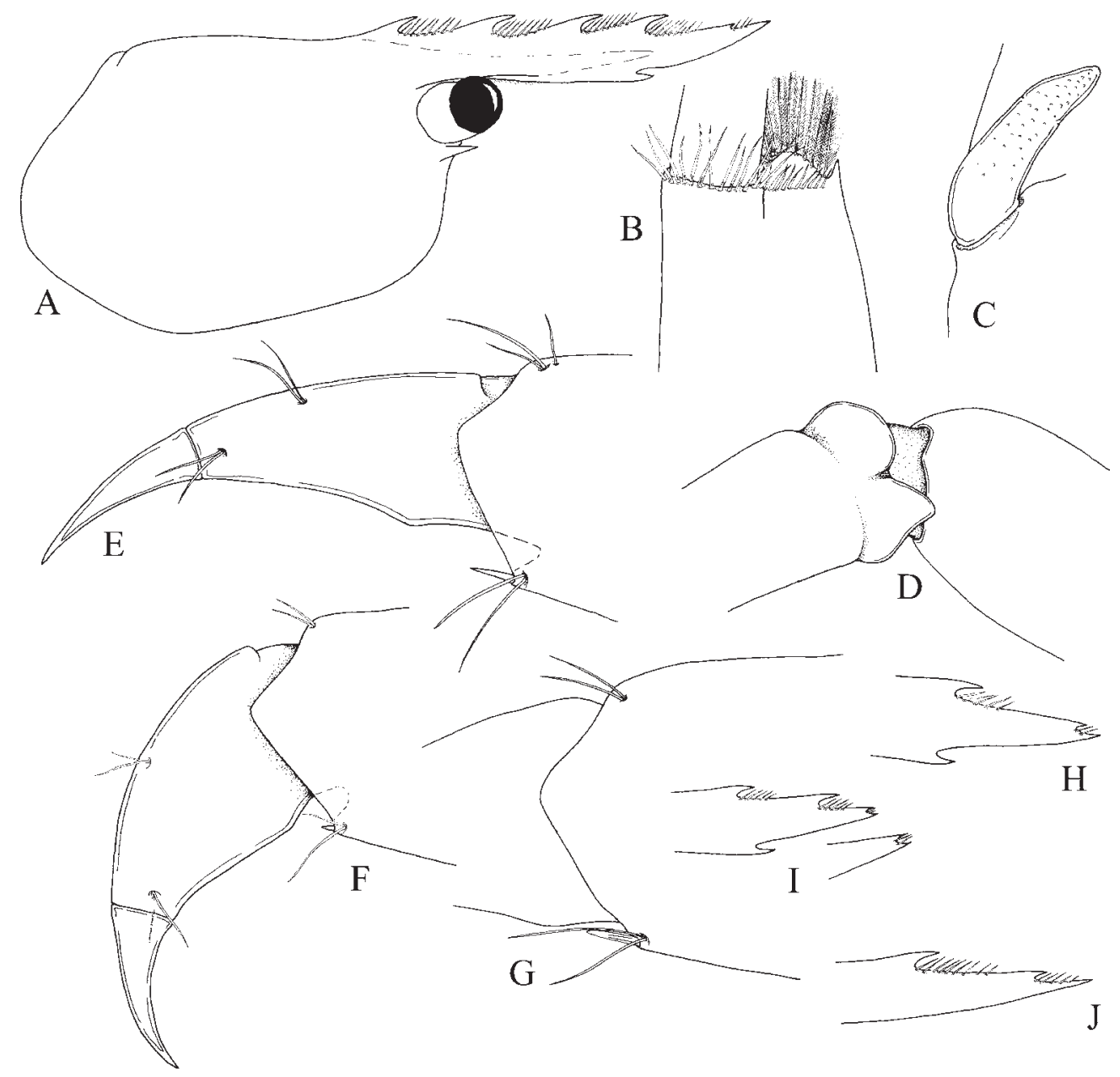

Fig. 2. Vir euphyllius Marin et Anker, 2005.

A - carapace and rostrum of mature male, $\mathrm{PCL}-3.7 \mathrm{~mm}$, from coral Euphyllia divisa; B — distal edge of basal antennular segment; $\mathrm{C}$ - mandibular palp; $\mathrm{E}$ - dactylus of third pereiopod of ovigerous female (PCL - $4.2 \mathrm{~mm}$ ); $\mathrm{D}$ - carpo-propodal articulation of second pereiopod; $\mathrm{F}$ - dactylus of third pereiopod of ovigerous female ( $\mathrm{PCL}-3.7$ $\mathrm{mm}) ; \mathrm{G}$ - dactylus of third pereiopod of ovigerous female ( $\mathrm{PCL}-5.3 \mathrm{~mm}) ; \mathrm{H}, \mathrm{I}, \mathrm{J}$ - distal part of rostrum of ovigerous females (PCL $-3.7 ; 5.3$ and $4.5 \mathrm{~mm}$ respectively).

Рис. 2. Vir euphyllius Marin et Anker, 2005.

A — карапакс и рострум половозрелого самца, $\mathrm{PCL}-3,7$ мм, с коралла Euphyllia divisa; B — дистальный край базального сегмента антеннул; C — мандибулярный щупик; $\mathrm{E}$ - дактилус третьих переопод яйценосной самки (PCL - 4,2 мм); D - карпо-проподальное сочленение вторых переопод; F - дактилус третьих переопод яйценосной самки (PCL - 3,7 мм); G - дактилус третьих переопод яйценосной самки (PCL - 5,3 мм); H, I, $\mathrm{J}$ - дистальная часть рострума яйценосных самок (PCL $-3,7 ; 5,3$ и 4,5 мм, соответственно).

Coloration. Body and most appendages translucent with tiny red chromatophores; eyestalks with two red longitudinal stripes on frontal margin; conspicuous white stripe present between eyes; antennal and antennular flagella translucent (Fig. 6; see also in situ color photo in Marin et Anker, 2005). The red longitudinal lines of the eyestalks are characteristic of all species of the genus (except Vir orientalis; coloration of this species is still unknown) help with preliminary field identification of the representatives of the genus.

Remarks. Vir euphyllius presents a significant variation of the rostral formula, which can be expressed as $0-2+4-5 / 0-2$, although most of the 


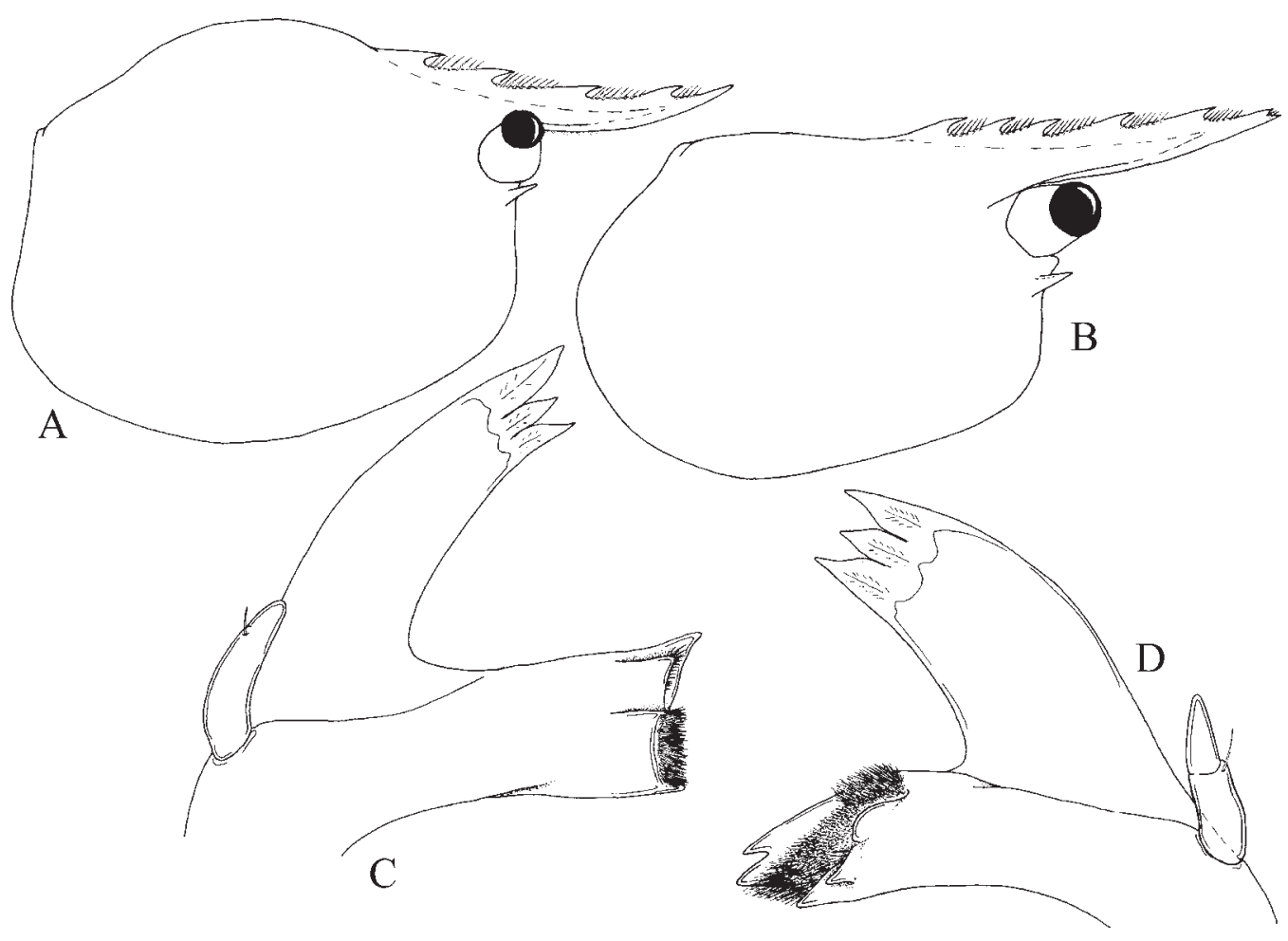

Fig. 3. Specimens of Vir euphyllius Marin et Anker, 2005 from coral Euphyllia glabrescens (Chamisso et Eysenhardt, 1821).

A - ovigerous female, PCL $-5.6 \mathrm{~mm}$; B - mature male, PCL $-3.0 \mathrm{~mm}$; $\mathrm{C}-\mathrm{D}$ - mandibules of the male.

Рис. 3. Экземпляр Vir euphyllius Marin et Anker, 2005 с коралла Euphyllia glabrescens (Chamisso et Eysenhardt, 1821).

A - яйценосная самка, PCL - 5,6 мм; В - половозрелый самец, PCL - 3,0 мм; C-D — мандибулы самца.

examined specimens have the rostral formula $0+4$ $5 / 1$ (Fig. 5). Similar variation in the number of rostral teeth, shape and length were also reported in other palamonids, for instance, Palaemon affinis Milne-Edwards (Yaldwin, 1957), Palaemon concinnus Dana (De Grave, 1999) and Onycocaris temiri Marin (Marin, 2005). The disto-ventral spines of the propodus of the third pereiopod vary from long (Fig. 2E) to reduced (Fig. 2F). No correlations between the body size and the length of this spine or the number of the rostral teeth were observed.

The previous report of a two-segmented mandibular palp in the holotype of $V$. euphyllius (Marin et Anker, 2005) should be considered as an error: a reexamination showed that this specimen has a onesegmented palp, as appears to be typical to this species. A two-segmented palp (Fig. 3D; Marin et Anker, 2005: fig. 6d) was observed in three dissected specimens (two males and one ovigerous female).
Noteworthy, all three specimens are lacking ventral teeth on the rostrum (Fig. 3), and in each specimen, only one of the two mandibles bears a two-segmented palp, whereas the other mandible has a normal one-segmented palp. Two of the specimens (male and ovigerous female) occupied the same host, while the remaining male was found in a pair with an ovigerous female bearing a normal, one-segmented mandibular palp and a rostrum with one ventral tooth. A slightly aberrant pair with similar morphological features was previously described as $V$. pareuphyllius (Marin et Anker, 2005). Two-segmented palp is known in $V$. orientalis and also in $V$. philippinensis (Holthuis, 1953; Bruce et Svoboda. 1984). Therefore, it is possible that the presence of a twosegmented mandibular palp in some specimens of $V$. euphyllius as an atavistic feature. Fujino et Miyake (1968) noted the same phenomenon in some representatives of the genus Palaemon Weber, 1795. 
Size and fecundity. The PCL of ovigerous females ranges between 3.2 and $5.6 \mathrm{~mm}$; males are significantly smaller with PCL ranging from 2.8 to $4.3 \mathrm{~mm}$. The largest specimen is an ovigerous female with CL $5.6 \mathrm{~mm}$ and TL about $19.0 \mathrm{~mm}$. Eggs are small (about $0.5^{\prime} 0.4 \mathrm{~mm}$ ) and numerous: two large females (5.0 and $4.8 \mathrm{~mm}$ ) bear 335 and 312 eggs, respectively.

Hosts. In Nha Trang Bay, all specimens of $V$. euphyllius were collected from colonies of the genus Euphyllia (Caryophyllidae). Three species of the genus, E. glabrescens, E. divisa and E. parancora, are presently known as hosts.

Ecology. All observed corals of Euphyllia spp. were inhabited by Vir shrimps. Small colony usually harbors one heterosexual pair, consisting of a mature female and a male, while larger host colonies may be occupied by several mature shrimps of both sexes and subadults (up to 12 mature females and 7 males on one colony with approximate diameter $1.5 \mathrm{~m}$ ). This distribution pattern suggests that $V$. euphyllius is characterized by some aggression to conspecifics and perhaps a joint (female-male pair) protection of the territory. Obviously, greater surface of larger colonies enables co-occurrence of several pairs of shrimps, each being possibly associated with a different corallite or a different patch of several corallites.

The shrimps were observed to move mostly on the surface of the tentacles. Alerted shrimps tried to hide in the crown of tentacles, moving among septae to the central valley of the corallite. The tentacles conceal almost completely the transparent body of the shrimps; only the distal carapace, eyes and chelipeds remain visible. Occasionally, alerted shrimps living far from the center of the corallite, moved to the opaque lateral side of the corallite. Vir philippinensis living on Plerogyra sinousa (Dana) acts in a very similar way (personal observation). Regenerating chelipeds as well as damaged rostra were marked. The traumas of the chelipeds are more likely to be the result of aggressive intraspecific interactions (e.g., see Marin, 2006), while rostrum injuries are more likely caused by predators.

Dissected stomachs of three specimens (two females and a male) contained flake-like mass consisting of zooxanthellae, cnidocysts, diatoms and green algae, as well as separate parts of the appendages of small arthropods (possibly small crustaceans such as copepods, and amphipods) . These observations suggest that the shrimps collect mucus from the polyp surface, occasionally ingesting other small organisms trapped in it, and also tweezing coral tissues.

Affinities. Vir euphyllius appears to be most similar to $V$. colemani. However, $V$. colemani may be separated from $V$. euphyllius by the shape of the

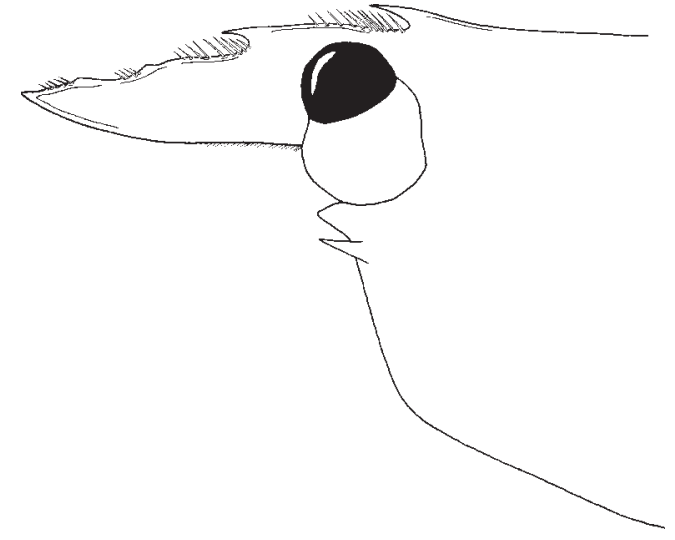

Fig. 4. Damaged rostrum of male of Vir euphyllius Marin et Anker, 2005 (PCL - $3.5 \mathrm{~mm}$ ) from coral Euphyllia parancora Veron, 1990. The specimen has also regenerated second pereiopods.

Fig. 4. Поврежденный рострум самца Vir euphyllius Marin et Anker, 2005 (PCL - 3,5 мм) с коралла Euphyllia parancora Veron, 1990. Для этого экземпляра также отмечены регенерирующие вторые переоподы.

distal margin of the carpus of the second pereiopods, absence of distoventral spine on the propodus of the third pereiopods, color pattern and ecology (see Marin et Anker, 2005). The following key allows separating all species of the genus Vir.

KEY TO THE KNOWN SPECIES OF THE GENUS VIR Holthuis, 1952

1. Mandible with 2-segmented palp. Rostrum with more than 6 dorsal teeth

- Mandible with 1-segmented palp. Rostrum with 4-5 dorsal teeth. ... 3

2. Rami of the lateral antennular flagellum with 6 segments. Propodus of third pereiopod about 7 times as long as wide, very setose distally. Freeliving or associated with pocilloporid corals .. Vir orientalis

- Rami of the lateral antennular flagellum with $11-$ 13 segments. Propodus of third pereiopod about 11 times as long as wide, sparsely setose distally. Associated with bubble coral, Plerogyra sinuosa .................................. Vir philippinensis

3. Distolateral margin of carpus of second pereiopods with 2 distinct lobes. Propodus of third pereiopods with distoventral spine (sometimes minute). Pereiopods transparent. Associated with hammer corals, Euphyllia spp.

Vir euphyllius 


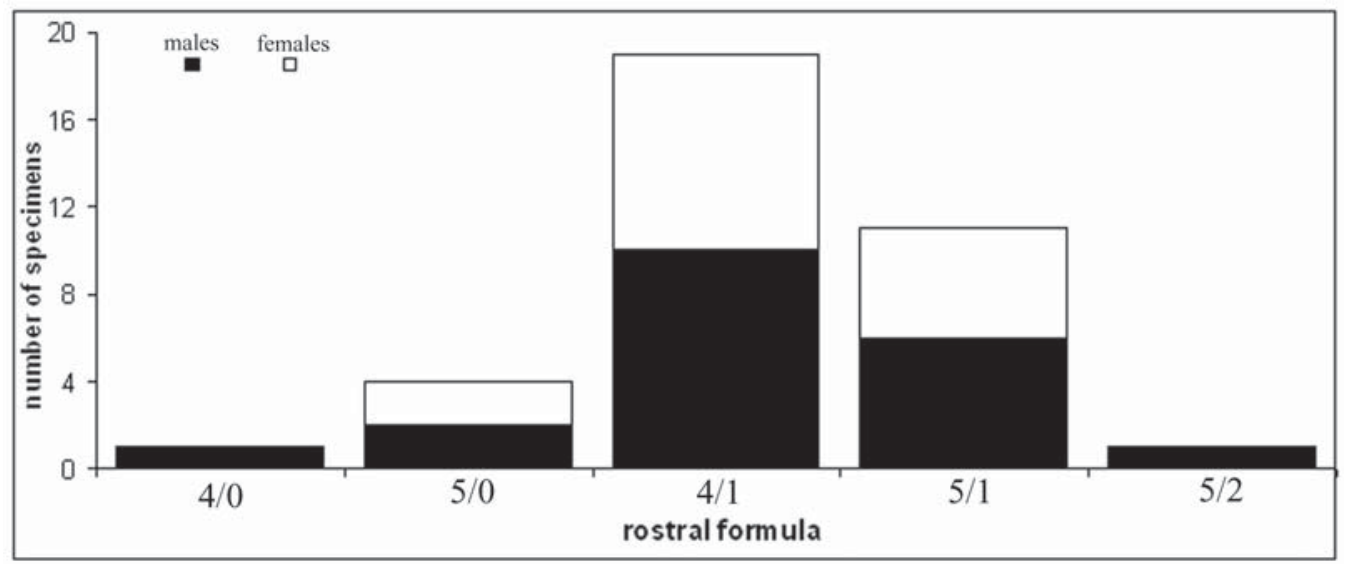

Fig. 5. Rates of different number of rostral teeth in Vir euphyllius Marin et Anker, 2005. Rostral formula comprises well developed teeth only. Specimens having rostrum with 4 well developed teeth and additional minute dorsal distal tooth and one ventral tooth were applied to group " $4 / 1$ " and so on.

Рис. 5. Соотношение различного числа ростральных зубцов у Vir euphyllius Marin et Anker, 2005. В ростральную формулу включены только хорошо развитые зубцы. Экземпляры с рострумом, несущим 4 хорошо развитых зубца, дополнительный мелкий дорсальный зубчик и один вентральный зубец, отнесены к группе «4/1» и так далее.

- Distal margin of carpus of second pereiopods with 1 lobe. Propodus of third pereiopods without distoventral spine. Pereiopods articulations with purple spots. Associated with bubble coral, Plerogyra sinuosa Vir colemani

Distribution. Western Pacific: Nhatrang Bay, Vietnam (Marin et Anker, 2005; present study); Cebu, Philippines (Bruce et Svoboda, 1984) and Hansa Bay, Papua New Guinea (De Grave, 2000).

\section{Discussion}

Presently, the genus Vir includes four species. Vir orientalis is known as free-living or associated with pocilloporid corals (Chace et Bruce, 1993; Fransen, 1994; De Grave, 2000), while the other three species are associated with corals of the family Caryophyllidae. Vir philippinensis and $V$. colemani are both associated with the bubble coral Plerogyra sinuosa (e.g., Bruce et Svoboda, 1984; Bruce, 2003), while Vir euphyllius is associated with three species of the hammer corals of the genus Euphyllia (Marin et Anker, 2005; present study). Thus most Vir species seem to be monoxenous, i.e., restricted to one host species (V.philippinensis, $V$. colemani) or closely related species from one genus ( $V$. euphyllius). Therefore, it may be assumed that the specimens reported as $V$. orientalis or $V$. philippinensis from other hosts, such as the caryophyllid coral Physogyra lichtensteini Edwards et Haime, 1851 (Fransen, 1994; De Grave, 2000) or the fungiid coral, Fungia sp. (Bruce et Svoboda, 1984), possibly represent undescribed species.

\section{Acknowledgments}

Material used in this study was collected with the support of the Russian-Vietnamese Tropical Center in Nhatrang City, Vietnam. Processing of the material was sponsored by RFFI project 05-04-48350. The author expresses his gratitude to the supervisor of the project "Marine Biodiversity of the Nhatrang Bay, Vietnam", Dr. T.A. Britayev (A.N. Severtzov Institute of Ecology and Evolution of the Russian Academy of Sciences, Moscow, Russia) and anonymous reviewers.

\section{References}

Bruce A.J. 2003. Vir colemani sp. nov., a new commensal pontoniine shrimp (Crustacea: Decapoda: Palaemonidae) from Papua New Guinea // The Beagle. Vol.19. P.119-124. 


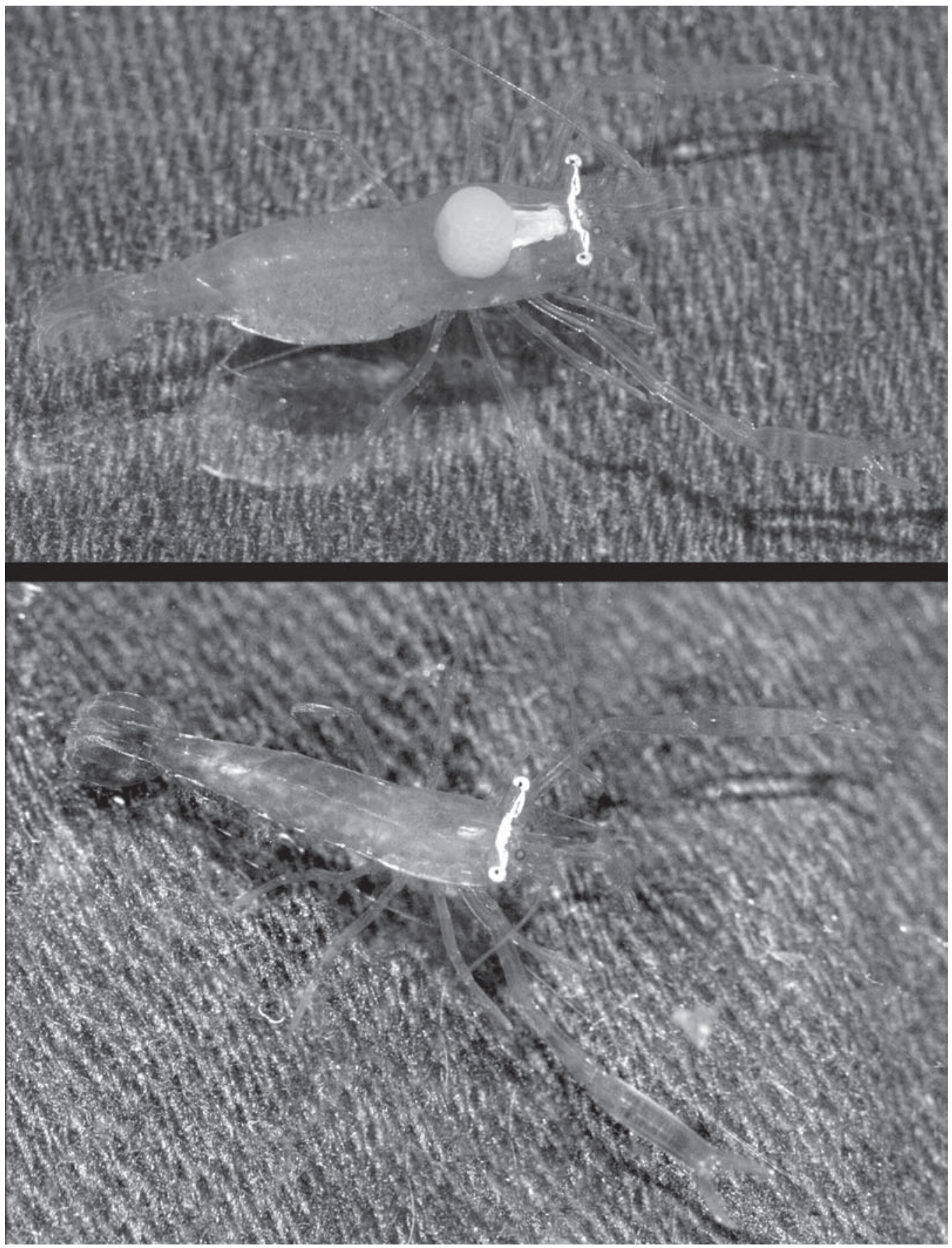

Fig. 6. Coloration of specimens of Vir euphyllius Marin et Anker, 2005 from corals Euphyllia divisa Veron et Pichon, 1980 (upper female) and Euphyllia parancora Veron, 1990 (lower male).

Рис. 6. Окраска особей Vir euphyllius Marin et Anker, 2005 с кораллов Euphyllia divisa Veron et Pichon, 1980 (самка вверху) и Euphyllia parancora Veron, 1990 (самец внизу). 
Bruce A.J., Svoboda.A. 1984. A report on a small collection of coelenterate-associated pontoniine shrimps from Cebu, Philippines Islands // Asian Marine Biology. Vol.1. P.87-99

Chace F.A., Bruce A.J. 1993. The caridean shrimps (Crustacea: Decapoda) of the Albatross Philippine Expedition, 1907-1910, part 6: Superfamily Palaemonoidea // Smithsonian Contributions to Zoology. Vol.543. $152 \mathrm{p}$.

De Grave S. 1999. Rostral variation in Palaemon concinnus Dana, 1852 (Decapoda: Palaemonidae) // Crustaceana. Vol.72. No.7. P.701-704.

De Grave S. 2000. Caridean shrimps (Crustacea, Decapoda) from Hansa Bay, Papua New Guinea: Palaemonidae and Gnathophyllidae // Bulletin de l'Institut Royal des Sciences Naturelles de Belgique, Biologie. T.70. P.119-148.

Fransen C.H.J.M. 1994. Marine palaemonid shrimps of the Netherlands Seychelles Expedition 1992-1993 // Zoologische Verhandelingen. Leiden. Vol.297. P.85152.

Fujino T., Myiake S. 1968. On the mandible of the genus Palaemon of Japanese palaemonid shrimps with the discussion of it taxonomic value // Occasional Papers of the Zoological Laboratory, Faculty of Agriculture, Kyushu University. Vol.1. No.10. P.191-200.

Holthuis L.B. 1952. The Decapoda of the Siboga Expedition, Part XI: The Palaemonidae collected by the Siboga and Snellius Expeditions, with remarks on other species, part II: Subfamily Pontoniinae // Siboga-Expeditie. Vol.39a. No.10. P.1-254.

Marin I.N. 2005. Pontoniine shrimps (Crustacea, Decapoda, Pontoniinae) from Viet Nam. Onycocaris temirisp. n., a new sponge-associated shrimp from Nha Trang Bay // Arthropoda Selecta. Vol.13. No.3. P.113-122.

Marin I.N. 2006. [Symbiotic community associated with corals of the genus Galaxea Oken (Cnidaria, Scleractinia): structure, biological interactions and ways of the formation]. Abstract of Ph.D. dissertation. Moscow: IPEE. 25 p. [in Russian].

Marin I., Anker A. 2005. Two new species of the genus Vir Holthuis, 1952 from Vietnam (Crustacea: Decapoda: Palaemonidae) // Arthropoda Selecta. Vol.14. No.2. P.117-128.

Yaldwin J.C. 1957. Studies on Palaemon affinis M.-Edw., 1837 (Decapoda Natanitia). Part II. Variation in the form of the rostrum // Transactions of the Royal Society of New Zealand. Vol.84. No.4. P.883-895.

Accepted April 20, 2007

Published online May 25, 2007 